\title{
ADHERENCE TO CONSUMER RIGHTS AND INCREASE IN SOCIAL RESPONSIBILITY OF BUSINESSES IN ACCORDANCE WITH THE EU STANDARDS ON PROTECTION OF CONSUMER RIGHTS: LESSONS FOR UKRAINE
}

\section{Khyzhniak V. O.}

\section{INTRODUCTION}

The sphere of protection of consumer rights is an integral part of the general human rights. Only consumers are not professional participants among all other market entities and they are not able to protect their legal rights efficiently without the state support. Just the satisfaction of consumer demands determines the level of development and civilization of market therefore in the context of development of the national economy this sphere is a realm of urgent and timely studies.

Reforming any sector of the national economy or the state's social block shall be, first of all, accompanied by changes in the corresponding legislative and regulatory-legal framework. Only in such a case can we count on a positive result. Thereby a number of important laws have been passed, in particular, the Law of Ukraine 'On state market supervision and control of non-food goods', the Law of Ukraine 'On responsibility for damages inflicted by defects in products', the Law of Ukraine 'On basic principles and requirements for safety and quality of food products'. At present the intensive work on harmonization of the Ukrainian standards with the European and world ones is carried out as well as the elaboration of necessary technical procedures. Therefore, if we count to attain a proper level of supplies of safe and quality goods to our citizens as a result of reforms in the system of protection of consumer rights there is also a need in 'rebuilding' of the system of technical regulation. As such a system is a base of the whole system of protection of consumer rights.

One of the indicators that characterize the development of any democratic society is a correspondence between civil rights and democratic liberties of every citizen.

One of the fundamental postulates of the sphere of protection of consumer rights recognized by international norms and practices is the freedom of a citizen to choose products and the consumer right to obtain quality products and information about them. 
Those fact that a consumer being a major participant of the consumer market and a principal investor in generation of business capitals and at the same time the most restricted in his/her rights person is paradoxical.

The issue of citizens' rights including the rights in the consumption sphere is urgent as the signing of the Agreement of Association with the EU by Ukraine will demand the application of the European standards on quality of products and the establishment of a basis for implementation the right of every citizen for an adequate level of consumed products and obtained services.

\section{Adherence to consumer rights and increase in social responsibility of businesses}

Analysis of recent studies and publications. The issues of protection of consumer rights and an improvement of businesses' social responsibility have been considered in the scientific publications of domestic scientists: Mandybura V. O., Zakhozhai V.B., Hryshova I.Yu., Krasnoruts'kyi O.O., Mytiai O.V., Shabatura T.S., Koniukhova Yu.M., Hnat'ieva T.M., Herasymova S.V, Paniuk T.P., Yazvins'ka O., Lazareva A., Nikolaieva L., Ivanenko L. and others. Nevertheless, a wide range of urgent issues in the context of the described problems demands further scientific studies.

Thus, according to Mandibura V.O. the issue of the matter of the social and economic category 'consumerism' remains urgent because it is nothing less than a systemic institution of manifestation of consumers' distrust in quality of goods and services available in the market and extension of the comprehension of the matter of mechanisms of systemic provisions for protection of consumer rights on the market of goods and services ${ }^{1}$. According to Hryshova I.Yu. activation of mechanisms of social responsibility of businesses in the context of increasing the competitiveness of economic entities and protecting the consumers' rights is one of the effective means of the consumer policy at the state level that indicates the process of transformations of the economic issues of social nature into value added that is generated by businesses for the account of transformations of its components, use of new competences and possibility of increasing market values ${ }^{2}$.

The purpose of research is a study of methodological approaches to social responsibility of businesses as it relates to consumers and protection of their rights under conditions of transformations of the national economy as well as a study of the organization of a system of customer rights

\footnotetext{
1 Закон України «Про відповідальність за шкоду, завдану внаслідок дефекту в

${ }^{2}$ Гришова І.Ю. Імплементація принципів соціально-орієнтованого бізнесу в площину економічного розвитку потенціалу харчових підприємств
} продукції» 
protection in the EU and possibility of using the useful experience of the European countries for improvement of the Ukrainian legislature in the sphere of protection of consumer rights and mechanisms of its implementation.

Presentation of the major results of the study. There are some basic methodological approaches to the conception of social responsibility that have been considered in scientific publications. In our opinion this conception not only relates to the principles of functioning of businesses in the market competitive environment but also remains one of the priority directions of the state policy in the field of protection of consumer rights ${ }^{3}$. In particular, this is a methodological approach according to which an economic entity is a tool for increasing the market value of business and obtaining additional profits and therefore any its social activity is directed on attaining economic outcomes. Performing such activities a business unit fulfills its economic function, producing goods and services which are necessary for the society and generating jobs and providing maximum profits for owners.

The socio-political approach is based on an assumption that businesses are able to exert some influence on the society and therefore they shall use this ability responsibly. This means the ability to affect the outcomes of important social processes with the aim to find solutions of social problems irrespective of political institutions. The most known conception is a conception of 'corporate citizenship' which formation began early in the early XXI century. According to this conception the role of a business in its narrow sense comes to philanthropy, social investments and some voluntary liabilities to the local society. In a wide sense the economic entity shall be responsible for those fields of its activities in which the state protects the rights of citizens as consumers at the market of goods and services.

The social approach implies the concentration of business activities on defining the social needs of the society and satisfaction of them contributing in that way to the strengthening of economic business positions. In view of this the activities of any businesses in the field of social responsibilities shall be defined by tasks the society entrusts them.

The moral and ethic approach is based on a conception of liabilities of business owners and some managers or enterprises to the society. Attitude of business in Ukraine toward the conception of social responsibility is defined, on the one hand, by the company's origin, its size, industry, location, activity, contacts with final consumers, a level of competitiveness un the market, the company's marketing strategies. On the other hand, the

\footnotetext{
3 Закон України «Про основні принципи та вимоги до безпечності та якості харчових продуктів»
} 
economic conditions in the country, the level of industry development and the correspondence to the current legislation are important.

Certainly, at present the national economy of Ukraine demands structural changes related to the harmonization of social and economic relations. Supplies of investments and reduction of tax burdens are required for widening of possibilities for small and average businesses which drive the economic development in many civilized countries. Then it will be valid to demand social responsibility from businesses and new approaches to the system of protection of consumer rights. Unfortunately the domestic consumer is forced to defend himself/herself permanently and creation of possibilities of full implementation of their rights for safety and quality of products as well as complete information about them is the major task of the state.

If we consider the European system of protection of consumer rights then at first sight it will seem liberal. This is due to a rather high culture level on the consumer market in Europe. For example, in Germany the level of civilized relations on the consumer market is about $95 \%$, in Poland - more than $70 \%$. For the Ukrainian market the estimated are not so favorable, only $20-25 \%{ }^{4}$.

The above gradation corresponds to the quality scale established in the world. By convention it may be divided in 15 stages and Ukraine, unfortunately, Ukraine is not even in the middle of this list. Therefore the system of protection of consumer rights in our country implies a similar state of quality of products and services. When the economic indices grow then the level of consumer market will rises.

At present an active work on harmonization of the Ukrainian legislative economic system with the European one is carried out. Such a work is a need as Ukraine clearly selects a way to the European integration and is a member of the World Trade Organization (WTO). However implementing reforms of the domestic economy we shall not forget those for whom we do all this, the Ukrainian consumers. Thus, the processes of development of businesses and improvement of the system of protection of consumer rights shall proceed in parallel and be interrelated.

In its turn, it is very important to adhere to the interests of manufacturers, traders and consumers in the process of elaboration of a modern model of the Ukrainian economy on the basis of innovation and investment development. Unfortunately, today these interests are wide asunder as pole and pole. The practice shows that the processes of economy deregulation are not directed on attainment of balance between interests of major participants

\footnotetext{
${ }^{4}$ Калита П. Звенья одной цепи: Защита потребителей и товаропроизводителей немислима без интегрирующей основы - качества
} 
on the consumer market. And what is more, they aggravate the imperfect system of protection of consumer rights. The reforms in the business sphere are taking place aggressively and infringe upon consumers' rights stipulated in the Constitution, the Law of Ukraine 'On protection of consumer rights' and other regulatory documents.

Sometimes the reforms in the economy of Ukraine are carried out without due allowance for consumer interests. This is caused by the orientation of the current conception of reforming the national economy on a rather rapid implementation into a civilized market. The major part of domestic businessmen makes every effort to be included into the world ratings. At that they absolutely forget or ignore the consumer rights. Though the consumer is above all an investor of the economy, a party who pays an equivalent for rendered services and supplied goods. Therefore the quality of goods that are included into the basket of goods shall be in accordance with labor that has been put into bought goods. Unfortunately the business not always takes this into consideration and tries to thrust low-grade services or services that do not correspond with their actual prices.

It is entirely obvious that the level of social responsibility of businesses depends on the level of development of both the economy and the society itself. And as the current quality indices of domestic businesses do not correspond to the average level of conducting business in Europe, where we strive for, our businessmen have a notion of social responsibility at a similar level.

First of all, business entities shall understand that the most reliable and profitable partner in development of business is a domestic investor, consumer of their products. Therefore he/she shall be treated with respect. Unfortunately, the practice shows that customers rather often buy products of unknown origin or with expired pull-dates, are cheated in weighing or counting or deceived with false consumer values of products.

We can't hope for rising the social responsibility of business until a favorable economic climate is established in Ukraine and manufacturers understand that customers are their reliable partners.

For some time past the legislation has developed not on the way to protection of consumer rights but other way. Due to efforts of lobbyists who stand up for interests of manufacturers the liberal attitude for those infringements which a manufacturer allows at the consumer market. For example, the changes inserted in the Law of Ukraine 'On protection of consumer rights' restrict the consumer rights in a case of buying low-grade goods. For example, if the consumer has bought a refrigerator and it turns out defective the consumer is given a right to remove defects within the warranty term. In essence, the consumer is obliged to perform repair without an opportunity of returning the defective goods to the trader. Only in a case 
when a complex procedure of expert evaluation is performed and the presence of any material defect of factory origin is confirmed the customer will acquire a right to exchange this goods or terminate a contract. Accordingly he/she will be given back the money but only after huge efforts!

Let's consider the Law of Ukraine 'On principles of the state supervision (control) in the field of economic activities' that at first sight reduces the pressure on business from the side of regulatory authorities. But, on the other hand, the legislation restrains the consumer rights even more. There is no such a conception as 'a 10-day notification about the check-up' in any country in the world. What is the sense in such a check-up? At best, the regulatory authorities will find the facility intended for check-up with removed defects. At worst, the auditors would find a lock on doors or absent management who emergently went on sick leave if they had had no time to hide the defect goods. Thus, the auditor arrives and establishes only the fact of the check-up. Also the periodicity of checks-up is not specified and should be established in accordance with a scale of risks while the notion of risk remains unspecified. In practice such a policy moves a businessman out of the field of supervision and regulation and leaves a consumer without any guaranteed protection of the law.

At present the most part of bills approved by the Parliament is directed on strengthening of businesses and stands up for the interests of enterprises and specific sectors of the economy. At that nobody says about the necessity to strengthen the social responsibility of businesses. The European experience indicates that the application of high economic penalties and sanctions may be an effective weapon in a struggle for the civilized market. First of all these sanctions shall be directed against selling of falsified or counterfeit products and products that are unsafe for human health and life. It's a different matter that the problem can't be solved by increasing only penalties.

It's obvious that for such violations as cheatings of consumers in counting and measuring it is necessary to decrease an amount of financial losses for which a prosecution is possible. Now such violations thrive in particular in markets and small shops. There are cases of product shortages, underfilling of spirits in catering outlets. To appeal to a businessman's or retailer's conscience is a bad job. The approaches shall be changed.

It is necessary to seek a balance: not only violators shall be punished financially but responsible businessmen shall be encouraged by economic preferences, decreased tax burden etc. Because of this businessmen will be interested in selling high-quality goods and rendering high-quality services.

It is necessary to reform the customer rights system. In its turn this depends on businessman's interests in proper conducting business activities. Just here there are roots of a new policy and reforms which may become a 
basis for development of corresponding regulatory and legal acts. It is necessary to arrange conditions under which the cooperation with consumers and respectful consideration of their interests will be profitable for manufacturers. In their turn customers shall have a well-defined and transparent protection system which shall guarantee the observance of all their constitutional rights.

\section{The eu standards on protection of consumer rights: lessons for Ukraine}

Protection of consumer rights is an urgent issue in the context of assurance of sectoral cooperation between the EU and Ukraine that is specified in the Agreement of Association between the EU and Ukraine (hereinafter as 'the Association'). The goal of the cooperation is harmonization of the current legislation of Ukraine with the legislation of the European Union to ensure the customer rights to high-quality and safe for health and life products and removal some 'gaps' between the European and Ukrainian systems of consumer rights protection. In particular, this cooperation comprises expert evaluations of legislative and institutional reforms, establishment of a standing system for exchanging data on unsafe products, refinement of information given to consumers especially about prices, characteristics of supplied goods or rendered services, training of official managerial persons and other representatives of consumers, development of exchanges between representatives of consumers and deepening of the policy in the field of consumer rights protection.

According to the Agreement of Association Ukraine is performing the step-by-step harmonization of the Ukrainian legislation with the EU legislation in the field of consumer rights protection specified in Appendix XXXIC to the Agreement of Association. At that time Ukraine tries to avoid creation of trade barriers.

According to Appendix XXXIX to Chapter 20 of the Agreement our country has 3 years for harmonization of the major part of documents and 5 years for harmonization with the Procedure No. 2006/2004 on cooperation in the field of consumer rights protection.

The protection of consumer rights in the field of sales is ensured by the corresponding provisions of the Laws of Ukraine 'On consumer rights protection', 'On the state market supervision and control of non-food products', 'On general safety of non-food products'. Unfortunately, the major part of the EU's secondary legal acts in the field of consumer rights protection are not implemented in full measure as there are some collisions in the current legislation of Ukraine that shall be corrected before the end of the implementation period of the Agreement of Association. 
First of all, it concerns contract laws, product safety, distance contracts signed beyond commercial facilities etc.

An economic mechanism of any society in which manufactured products are goods whose interchanges are carried out in accordance with the law of value will require the corresponding legal forms of arrangement of goods turnover and transition of goods from manufacturers to consumers.

As it is known, the contract is one of the most widespread reasons of the origin of civil liabilities. Just the contract of sales is a device that mediate relations concerning payable alienation of property from some persons in favor of others including those who are defined as consumer-buyers by the law.

One of the main constitutional rights of any citizen whose implementation demands the establishment of certain guarantees is a consumer right to acquire goods of proper quality. Thus, according to Article 50 of the Constitution of Ukraine: 'Every person shall have a right to the environment that is safe for health and life and compensation of damages inflicted as a result of infringement of this right. A right to free access to information about the environmental conditions, quality of food products and amenities as well as a right to disseminate such information are guaranteed. Such information shall not be classified as secret ${ }^{5}$.

The market of Ukraine is permanently saturated with various goods of domestic or foreign origin though they are not always of proper quality.

Some provisions of the Law of Ukraine 'On consumer rights protection', in particular Article 8 that defines the rights of consumer in a case of acquiring of goods of improper quality, restrict the consumer rights and do not account for all requirements specified in certain provisions of the European legislation, therefore such provisions shall be brought into accord with the EU laws with respect to renewal the customer right to change products of low-grade and compensation for damages.

According to Article 8 the customer rights are differentiated into the rights for goods bought with 'defects' and the rights for goods bought with 'material defects'. In a case of acquisition of goods with defects the customer has a right to demand a proportional decrease in the price from the trader or manufacturer, free elimination of defects in goods within a reasonable period of time or compensation of expenditures for elimination of defects in goods.

Only in a case of detection of material defects the consumer has a right to demand termination of the contract and repayment. At that just the consumer shall provide the major part of the basic evidence of presence of material defects, that is the consumer shall apply such a legal framework in which the

\footnotetext{
${ }^{5}$ Конституція України
} 
presence of a material defect shall be only established by means of logical interpretation of the consumer rights. This significantly complicates the realization of his/her rights to termination of the contract and repayment.

It is necessary to consider the notion 'material defect' profoundly. According to the Law the 'material defect' is a defect that makes the use of goods impossible or inadmissible for its target purpose; it has originated from a fault of the manufacturer (trader, contractor); after removal the defect occurs again as a result of causes that are independent of consumer's actions. At that such a defect posses at least on of the following features: it can't be removed at all; or for its removal more than fourteen days will be required; or it makes the goods significantly different from what the contract provides for.

Thus the consumer can terminate the contract of sales and get his/her money paid for the recently bought low-grade goods back only in a case when the defect is material and certified on a proper way by a service center that renders services and performs repairs of consumer goods. Therefore the consumer can demand repayment from this trader of goods subject to the ascertainment of the failure (the material defect) from the fault of the manufacturer or trader and after attempts to remove the defect of goods.

At the same time Article 3, Directive 1999/44/ EC, which concerns some aspects of sales of consumer goods and related warranties and stipulates the consumer rights when the goods of improper quality have been purchased, gives a consumer the right to free removal of defects by means of replacement or repair of the goods, or decreasing their price, or termination of the contract related to the goods. At that the above-mentioned Directive does not stipulate any differentiation of defects into 'defects' and 'material defects', and termination of contracts is possible in a case of any incompatibility of goods.

At the same time, according to item 6, Article 3, Directive 1999/44/ EC a consumer does not have a right to terminate the contract if incompatibility is insignificant.

This European practice may be useful for the Ukrainian legislator. A legal provision that gives a consumer the right to change the goods of improper quality or terminate the contract of sales when he/she has purchased the goods with defects or the goods do not comply with the requirements for them or the terms of contract shall be applied in the legislation of Ukraine concerning the consumer rights protection.

Only some groups of goods of improper quality may be excluded: defects in buildings or structures, cars, pieces of furniture, which has been sold or manufactured with defects that may be removed without significant material expenditures. For example, when a car has been sold with a defected inoperative headlight or other auxiliary it is impractical from economic point 
of view to give a customer the right to unconditional termination of the contract of sales.

Assurance of a competent selection of goods, work, or services is the main purpose of provision of information about them. Such information shall include the designation of goods, their quality, conditions of use, warranties and others. The manufacturer (contractor, trader) shall define the required scope of such information on his/her own. At that he/she shall remember his/her responsibility for incompleteness of provided information according to the law.

According to the Law of Ukraine 'On consumer rights protection' a consumer has a right to get necessary, accessible, reliable and timely information about products as the assurance of the possibility of deliberate and competent choice of them. In particular, Article 15 of the Law regulates the consumer right to get necessary, accessible, reliable and timely information which shall include the following:

1) name of goods, designation or reproduction of a mark for goods and services under which they are sold;

3) data on basic properties of products, rated quantity (mass, volume, etc), conditions of usage;

4) information about the content of harmful for health substances which are designated by the regulatory and legal acts and the warnings relating to the application of some products if such warnings are set by the regulatory and legal acts;

5) note of presence of genetically modified organisms in the product composition;

6) data on price (tariff), terms and rules of acquisition of products;

6-1) if doubtful information about products has been revealed (under the stipulation that the products are not harmful for life, health or property of the consumer) the manufacturer (trader) shall withdraw the products from the market and bring the information into accord;

7) date of production;

8) information about terms of storage;

9) manufacturer's (contractor's) warranty;

10)rules and terms of safe and effective use of products;

11)expiration date (service life) for the goods (consequences of work), information about necessary actions of the consumer after the expiration date and possible consequences if they will not be fulfilled;

12)name and location of the manufacturer (contractor, trader) and a company which performs his/her functions related to claims of the consumer as well as repair and maintenance operations.

Directive EC No. 1169/2011 of 25.10.2011 'On provision of food information for consumers' has an object of attaining a high level of 
protection of consumers' health and guaranteeing their rights to get information. This object is assured by proper distribution of information about consumed food products among the consumers. Customers' choices of food products may be affected (but not limited to) by the marking related to health, economic issues, protection of environment, social or ethical issues.

The analysis of Directive EC No. 1169/2011 of 25.10.2011 'On provision of food information for consumers' shows that in addition to the basic information about a food product for provision of which consumers have the right it also regulates the requirements for food producers to indicate the information about a country and place of food origin.

This means that in accordance with the Agreement of Association Ukraine shall bring the Law of Ukraine 'On consumer rights protection' into accord with the above-mentioned Directive in regards to insertion of changes related to the indication of information about country and place of origin of food products on their labels.

The necessary information about products means it completeness. The current legislation of Ukraine is based on the assumptions that consumers do not have sufficient knowledge of goods, work or service they want to consume. But the trader (manufacturer, contractor) is a professional who knows all about the goods to be sold, the job to be done or the service to be rendered. Therefore he/she shall provide the information for consumers in such amount that they can obtain a clear idea of product properties, its quality, safety, rules of usage, and on the basis of this information consumers can make a competent choice of products which are required and suitable for them.

In addition, there is no any provision for indication of the production lot which is one of the compulsory component of the compulsory information about food products in the Law of Ukraine 'On consumer rights protection'. In that way, owing to this indication on the food product introduced into the market the production lot related to this product can be identified. According to item 59, Part 1, Article 1 of the Law of Ukraine 'On basic principles and requirements to safety and quality of food products' 'a lot is any amount of food products under the same name and with the same properties, this amount is determined by the market operator and produced for the period of time which is determined by this operator, under the same production conditions and at the same facility'. Part 6, Article 37 of this Law stipulates that 'when any unsafe food product is a part of a lot or shipment of food products of the same designation it shall be considered that all food product under this designation in this lot or shipment are also unsafe and their further turnover shall be prohibited until the next detailed evaluation will demonstrate that the rest of the lot or shipment is safe'. So, the number of production lot is one of the integral component of the compulsory 
information about the food products and the compulsory requirement to the marking of food products (paragraph 10, item 6 of the approved order of the State Committee of Ukraine on issues of technical regulations and consumer policy of 28.10.2010, registration number 487 'On approval of the Technical Procedures related to the marking rules for food products'). Thereby, we consider that the Law of Ukraine 'On consumer rights protection' shall be supplemented with the provisions for identification a production lot as the compulsory information that shall be provided for. Therefore it is advisably to provide the procedural requirements for identification of a production lot of food products.

In the field of consumer rights protection an urgent issue is an unfair practice of product sales applied by economic entities in relations with consumers. In the EU such a practice is named 'unfair commercial practices'.

Thus, according to Article 1 Directive No. 2005/29/EC of 11.05.2005 on unfair commercial practices is intended to assure proper functioning of the internal market and attain a high level of consumer interests protection by bringing the laws, resolutions, administrative provisions of the memberstates concerning unfair commercial practices that are harmful for economic interests of customers into accord. The directive is applied to business-toconsumer practices that are used before, during or after signing a contract related to the product (Part 1, Article 3).

The Directive is a legislative enactment of maximum harmonization therefore the member-states don't have any right to keep or adopt any additional rules in this field at the national level.

Articles 5 to 9 of the Directive describe unfair commercial practices. The Directive prohibits both actions and inactivity that deceive as well as aggressive commercial practices including the use of molestation, compulsion and abuse of power. Annex 1 to the Directive comprises specific examples of commercial practices which in any case are considered as unfair. The list comprises 23 examples of unfair and 8 examples of aggressive practices.

The member-states shall ensure the existence of independent and effective measures to counteract unfair commercial practices and comply with the provisions of the Directive in the interests of consumers (Part 1, Article 11). Such measures include the right of private persons or institutions having legal interests in combating unfair commercial practices (including their competitors) to take legal measures against such practices (go to the law or appeal to other state authorities). The member-states shall establish effective, proportional and retaining sanctions for infringement of the national legislation that implements the provisions of the Directive (Article 13). 
The issues of unfair (dishonest) commercial practices in Ukraine are regulated by the Laws of Ukraine 'On consumer rights protection' and 'On protection against unfair competition'.

According to Part 1, Article 19 of the Law of Ukraine 'On consumer rights protection' any business practice that is dishonest shall be prohibited. Such a practice includes: commission of actions or inactivity, which deceive the consumer or are aggressive, or manifestation of unfair competition. For every type of unfair practice the Law gives a corresponding example whose list is not exhaustive. Also the important provision is item 1, Part 1, Article 21 of the Law of Ukraine 'On consumer rights protection'. According to this provision the consumer rights shall be considered as violated when during the realization of product the right of consumer to free choice of products is violated in some way. Article 22 of the Law regulates the issues of remedial measures.

The provisions for prohibition of unfair (dishonest) commercial practices in the current legislation of Ukraine are very similar with the Laws of the EU. The given examples of unfair practices stipulated in Article 19 of the Law 'On consumer rights protection' cover a great number of examples listed in Annex 1 to the Directive. Nevertheless not all compulsory provisions of Directive No. 2005/29/EC are taken into account in the Ukrainian legislation. For example, the notion of unfair commercial practice by the Directive does not correspond with the notion of dishonest business practice by the Law of Ukraine 'On consumer rights protection'. Taking into account the Directive's nature as the enactment of maximum harmonization it is necessary to bring the list of examples of deceitful and aggressive practices stipulated in the Ukrainian legislation into accord with the list presented in Annex 1 to the Directive. Furthermore, there some discrepancies in the characteristic of the notions 'misleading commercial practice' (Article b I 7 of the Directive) and 'dishonest business practice that deceives' (Part 2, Article 19 of the Law). The Law of Ukraine 'On consumer rights protection' does not account the corresponding provisions of the Directive.

\section{CONCLUSIONS}

In our opinion the most comprehensive and substantiated methodological approach is the disclosing of economic content of the attribution 'Social responsibility of business' according to which a contribution of the economic entity into the society, which has been created with the use of the company's social investments, its basic activities and charity, allows the execution of its functional tasks of a business unit subject to requirements and rights of consumers in the market of goods and services. 
Protection of consumer rights in the field of commerce is assured by the corresponding provisions of the Laws of Ukraine 'On consumer rights protection', 'On state market supervision and control of non-food products', and 'On general safety of non-food products'. The major part of the EU's secondary legal acts in the field of consumer rights protection have been underimplemented, there are some collisions in the current legislation of Ukraine, which shall eliminated in accordance with the Agreement of Association between the EU and Ukraine.

According to the current legislation of Ukraine the customer can terminate the contract of sales and recover money for low-grade goods bought recently only in a case if the detected defect is material and certified in a certain way by a corresponding service center that performs maintenance and repair of consumer goods. Therefore, the customer can demand repayment from such a trader of goods under the condition that it has been established that defects (material defects) had occurred through the manufacturer's or trader's fault and only after attempts to repair the goods. At the same time Article 3 of Directive No. 1999/44/EC concerning some aspects of sales of consumer goods and related warranties gives customers the right to free removal of defects by replacement or repair the goods, or price reduction, or termination of the contract related to these goods. According to the Agreement of Association Ukraine shall bring the Law of Ukraine 'On consumer rights protection' as regards the insertion of changes related to the indication of information about the country and place of goods origin on food-products with the above-mentioned Directive.

Also, the Law of Ukraine 'On consumer rights protection' doesn't contain a provisions for identification of a production lot while such information is a compulsory part of the compulsory information about food products according to the EU's standards.

The provisions for prohibition of unfair (dishonest) commercial practices in the current legislation of Ukraine are very similar to the EU's laws. The examples of unfair practices that are provided and shown in Article 19 of the Law 'On consumer rights protection' cover many examples contained in Annex 1 to the Directive. Nevertheless not all compulsory provisions of Directive No. 2005/29/EC have been taken into account in the current legislation of Ukraine.

\section{SUMMARY}

Reformation of the economy, harmonization of the Ukrainian legislation with the European standards, and arrangement of favorable conditions for development of businesses shall be coordinated with improvements in the system of protection of consumer rights and raising social responsibility of business. That is why the analysis of experience in assurance of legitimate 
consumer rights related to products safety and quality is an important part of the scientific support for development of these processes under domestic conditions in the context of the general process of market reforms and strengthening the social responsibility of businesses.

The work deals with the EU standards on consumption which are designed for establishment of a high level of consumer rights protection for free movement of goods in the EU's internal markets. The main issues of consumer rights protection in Ukraine have been considered in the context of harmonization of the current legislation of Ukraine with the legislation of the European Union for the purpose of improvement of end-products safety and quality.

\section{REFERENCES}

1. Закон України «Про відповідальність за шкоду, завдану внаслідок дефекту в продукції» від 19.05.2011 р. № 3390-VI [Електронний pecypc]. - Режим доступу : zakon.rada.gov.ua/laws/show/3390-17

2. Гришова І.Ю. Імплементація принципів соціально-орієнтованого бізнесу в площину економічного розвитку потенціалу харчових підприємств/ І.Ю. Гришова, Т.С.Шабатура// Економіка: реалії часу. Науковий журнал. - 2014. - № 3.- С. 13-22. - Режим доступу до журн.: http://economics.opu.ua/files/archive/2014/n3.html

3. Закон України «Про основні принципи та вимоги до безпечності та якості харчових продуктів» від 22.07.2014 p. № 1602-VII [Електронний ресурс]. - Режим доступу : http://radakmu.org.ua/uploads/ file/-/280915_01.pdf.

4. Калита П. Звенья одной цепи: Защита потребителей и товаропроизводителей немислима без интегрирующей основы качества /П.Калита- Споживач. - 1997 - № 8.

5. Конституція України [Електронний ресурс]. - Режим доступу : http://zakon3.rada.gov.ua

6. Закон України «Про захист прав споживачів» від 12.05.1991 р. № . № 1023-XII [Електронний ресурс]. - Режим доступу : zakon.rada.gov.ua/laws/show/1023-12.

7. Закон України «Про державний ринковий нагляд і контроль нехарчової продукції» від 02.12.2010 p. № 2735-V [Електронний pecypc]. - Режим доступу : zakon.rada.gov.ua/laws/show/2735-17.

8. Захожай В.Б. Управління якістю: навч. посіб. для студ. вищ. навч. закл. /В.Б. Захожай, Н.Г. Салухіна, О.М. Язвінська, А.Ю. Чорний; за наук. Ред.. В.Б. Захожая. - К.: ДП «Вид. дім «Персонал», 2011. - 936 с.

9. Мандибура В. О. Особливості формування Інституту довіри в системі забезпечення якості споживання та захисту прав споживачів / 
В. О. Мандибура, С. Г. Батажок // Вісн. Ін-ту економіки та прогнозування. - 2009. - № [1]. - С. 69-73.

10. Гришова І.Ю. Соціальна відповідальність бізнесу як чинник соціально-економічного розвитку / І.Ю. Гришова, М.Ю. Щербата, В.В.Гришов// Проблеми і перспективи економіки та управління : науковий журнал / Черніг. нац. технол. ун-т. - Чернігів : Черніг. нац. технол. ун-т, 2015. - № 3 (3). - С. 17-28.

11. Герасимова С.В. Узагальнення підходів до визначення консюмеризму як соціально-економічної категорії // Актуальні проблеми економіки. - 2005. - № 12. - С. 76-79

12. Гнатьєва Т.М. Соціальна відповідальність бізнесу як інструмент ефективності корпоративної стратегії/ Т.М. Гнатьєва // Вісник Чернігівського державного технологічного університету. - Чернігів. 2014. - № 2(74). - С. 35-45.

13. Гнатьєва Т.М. Вплив соціальної відповідальності бізнесу на конкурентоздатність підприємств аграрного сектору / Т.М. Гнатьєва, О.В. Ніколюк // Вісник Чернігівського державного технологічного університету. - Чернігів. - 2014. - №4(76). - С.151-158.

14. Красноруцький О.О. Концептуальні засади здійснення корпоративної соціальної відповідальності харчовими та переробними підприємствами / О. О. Красноруцький // Науковий вісник Херсонського державного університету. Серія «Економічні науки». Вип. 10. - Ч. 3. - 2015. - С. 52-54.

15. Панюк Т. П. Роль соціальної відповідальності бізнесу в діяльності молокопереробних підприємтсв. / Т. П. Панюк // Проблеми і перспективи економіки та управління : науковий журнал / Черніг. нац. технол. ун-т. - Чернігів : Черніг. нац. технол. ун-т, 2015. - № 2 (2). C. $118-122$.

16. Митяй О.В. Социальная ответственность бизнеса как направление улучшения социального развития агропромышленных предприятий / О.В. Митяй // Социальная ответственность бизнеса: международная научно-практическая конференция (Тольятти, 10-11 декабря 2014 года): сборник научных трудов / отв. ред. Ю.А. Анисимова. - Тольятти: Изд-во ТГУ. - 2014.- С. 46-56

17. Закон України «Про державний ринковий нагляд і контроль нехарчової продукції» від 02.12.2010 р. № 2735-V [Електронний pecypc]. - Режим доступу : zakon.rada.gov.ua/laws/show/2735-17.

18. Закон України «Про загальну безпечність нехарчової продукції» від 02.12.2010 р. № 2736 - VI [Електронний ресурс]. - Режим доступу : zakon.rada.gov.ua

19. Язвінська О.М. Історія консьюмеризму в США / О.М. Язвінська // Гуманітарні науки і сучасність. - К., 2002. 
20. Лазарева А. Захист споживачів у Франції /А. Лазарева // Споживач. - 1997. - № 7.

21. Захист прав споживачів: соціально-правовий аспект /За заг. ред. Л.В. Ніколаєвої. - К.: КНТЕУ, 2002. - С.312.

22. Іваненко Л.М. Правове регулювання захисту прав споживачів: Навч. посіб. - К.: КНТЕУ, 2008. - С.258.

23. Лащак В.В., Лащак Т.В. Система захисту прав споживачів у провідних країнаї світу /В. Лащак, Т. Лащак //Наукові записки «Острозької академії», серія «Економіка», випуск 25, 2014 р. - С. 15-18.

\section{Information about authors:} Khyzhniak V. O.,

Candidate of Economic Sciences, Director of the State Enterprise, «Research Institute of Building Production named of V.S. Balitsky» 51, Lobanovskyi av., Kyiv, 03110, Ukraine 